\title{
Effect of Plant Growth Regulators on Fruit Set and Yield of Summer Crop in Acid Lime (Citrus aurantifolia Swingle) cv. Balaji
}

\author{
G. Ranganna*, K.T. Venkataramana, L. Mukundalakshmi, \\ K. Swarajyalakshmi and P. Sudhakar
}

\author{
Horticultural College and Research Institute, Anantharaju Peta, Dr. YSR Horticultural \\ University, Andhra Pradesh, India \\ *Corresponding author
}

\section{A B S T R A C T}

A field study was conducted at AICRP on Citrus, Citrus Research Station, Tirupati, Andhra Pradesh during the year 2015 under Dr. YSR Horticultural University, to find out Effect of Plant growth Regulators on fruit set and yield parameters of summer crop in acid lime (Citrus aurantifolia Swingle) cv. Balaji. Trees were sprayed with treatments viz.

\section{Keywords}

Plant growth regulators, Acid lime, Fruit set, Yield.

Article Info

Accepted:

26 May 2017 Available Online: 10 June 2017
Spraying $\mathrm{GA}_{3} @ 50$ ppm during June + CCC @ 1000 ppm during September + $\mathrm{KNO}_{3} 2 \%$ during October, Spraying CCC @ 200 ppm (Chloromequat chloride) $1^{\text {st }}$ in August, $2^{\text {nd }}$ in September followed by light pruning in September and heavy irrigation in mid-October, Application of Paclobutrazol @ $5 \mathrm{ml}$ per meter canopy 4 times at 45 days interval starting from July to December, Spraying NAA @ 200 ppm during December, Spraying 2, 4-D @ 40 ppm during November +20 ppm during February, Imposition of 30 days of soil moisture stress during October followed by $50 \mathrm{ppm}$ Ascorbic acid spray at release of stress, Spraying ethephon @ 200 ppm during the month of October, With holding irrigation (Bahar) for 30 days in September followed by application of recommended dose of fertilizers and irrigation in the month of November and along with control (Not spray). The data recorded from the results concluded that higher fruit set was recorded with the treatment application of 2, 4-D @ 40 ppm during November +20 ppm during February $\left(\mathrm{T}_{5}\right)$, highest number of fruits per shoot was recorded with application of Paclobutrazol @ $5 \mathrm{ml}$ per meter for four times starting from July to December $\left(\mathrm{T}_{3}\right)$, lowest fruit drop percent was recorded with spraying of 2, 4-D @ 40 ppm during November +20 ppm during February $\left(\mathrm{T}_{5}\right)$, number of fruits per tree was recorded with the treatment application of Paclobutrazol @ $5 \mathrm{ml}$ four times starting from July to December $\left(\mathrm{T}_{3}\right)$ and Spraying $\mathrm{GA}_{3}$ @ 50 ppm during June + CCC @ 1000 ppm during September + $\mathrm{KNO}_{3} @ 2$ \% during October $\left(\mathrm{T}_{1}\right)$ has recorded significantly highest fruit yield per tree.

\section{Introduction}

In India, among the fruit crops citrus species covers an area of major fruit crops is $10.4 \%$ with an area of 953.40 thousand ha, with production of $1,17,42,000 \mathrm{MT}$, giving rise to Productivity of 8.7 MT per ha estimated data NHB 2015-2016. As per the data available (AP Horticulture online 2015-16), in Andhra
Pradesh oranges and Batavia are being cultivated in 1, 21, 716 hectares with the production of $1,40,78,216 \mathrm{MT}$ and limes and lemons are grown an area of 111.09 thousand ha with production of 1717.34 thousand MT and productivity of $16.8 \mathrm{MT}$ per hectares during 2015-2016 (NHB, 2016.). 
Citrus is one of the largest and most important groups of fruit crops in tropical and subtropical regions. Acid lime (Citrus aurantifolia Swingle) is considered as most important fruit crop (Ghosh, 1990). It is considered to be native of Malayan peninsula. It belongs to the family Rutaceae, with chromosome number $(2 \mathrm{n}=18)$. It is mainly cultivated for its multi - fold nutritional and medicinal values which made acid lime more important among the fruits.

Its attractive appearance, penetrating aroma of peel and excellent taste gives a remarkable position to acid lime which is grown widely throughout the world (Babu, 2001). Acid lime fruits have great medicinal value. Being acidic in nature, acid lime fruits have great medicinal value. Acid lime is good appetizer, anti helmentic and it checks biliousness and stomach ache. Lime is used in making candy, chocolate, ice cream, pastries and 100 grams of fruit juice contains 80 percent of water, carotene, $26 \mathrm{IU}$, Vitamin A, Vitamin $\mathrm{B}_{1} 20$ $\mathrm{mg}$, Riboflavin $0.1 \mathrm{mg}$, Vitamin C $63 \mathrm{mg}$, Iron $(\mathrm{Fe}) 1.83 \mathrm{mg}$, Copper $(\mathrm{Cu}) 0.16 \mathrm{mg}$, Oxalo-acetic acid $0.30 \%$, Malic acid and alkaline salt $8.2 \%$ therefore it is very essential for human health (Rangel, 2010).

The major constraints faced by the growers of acid lime are the peak and lean production in consecutive years. Flowering in acid lime is recurrent under tropical and sub-tropical conditions unless synchronized into welldefined period of extreme stress. Since the demand for the fruit remains very high during summer it is very essential to regulate flowering that gives fruiting in the months of April and May which fetches higher returns to the grower compared to the income receive during other seasons.

There is difficulty in fruit set because of incomplete pollination, hence plant growth regulators may be effectively used to increase fruit set. Hasta-bahar (September - October) management through the use of plant growth regulators and chemicals play an important role to get maximum fruit yields during summer (Mukunda et al., 2014). Hence there is a need to test the plant growth [hasta-bahar (September - October)] through the use of plant growth regulators and chemicals for their role inducing flowering for the hasta bahar crop.

\section{Materials and Methods}

The present investigation were executed at AICRP on Citrus, Citrus Research Station, Tirupati, Andhra Pradesh during the year 2015 under Dr. YSR Horticultural University with nine treatments viz., Spraying $\mathrm{GA}_{3} @ 50$ ppm during June + CCC @ 1000 ppm during September $+\mathrm{KNO}_{3} 2 \%$ during October, Spraying CCC @ 200 ppm (Chloromequat chloride) $1^{\text {st }}$ in August, $2^{\text {nd }}$ in September followed by light pruning in September and heavy irrigation in mid-October, Application of Paclobutrazol @ $5 \mathrm{ml}$ per meter canopy 4 times at 45 days interval starting from July to December, Spraying NAA @ 200 ppm during December, Spraying 2, 4-D @ 40 ppm during November + 20 ppm during February, Imposition of 30 days of soil moisture stress during October followed by $50 \mathrm{ppm}$ Ascorbic acid spray at release of stress, Spraying ethephon@ @200 ppm during the month of October, With holding irrigation (Bahar) for 30 days in September followed by application of recommended dose of fertilizers and irrigation in the month of November and along with control (Not spray).

The experiment was laid out in a randomized block design with three replications. The effect of different treatments was studied on fruit set parameters and yield on six randomly selected trees. The mean data were subjected to statistical analysis following analysis of variance technique (Panse and Sukhathme 1985). 


\section{Results and Discussion}

\section{Percentage of fruit set}

The percentage of fruit set in each treatment was recorded and found significant among the treatments. Significantly higher fruit set $(89.97 \%)$ was recorded on the trees sprayed with 2, 4-D @ 40 ppm during November + 20 ppm during February $\left(T_{5}\right)$ which was found on par (89.67 \%) with spraying CCC @ 200 ppm first in August, second in September followed by light pruning in September and heavy irrigation in mid-October $\left(\mathrm{T}_{2}\right)$. However, the percentage of fruit set was lowest $(65.16 \%)$ in control treatment. The results are in accordance with the findings of Thirugnanavel et al., (2007) who reported higher fruit set by application of $\mathrm{GA}_{3}$ which might have influenced pollen germination and pollen tube growth.

Further increase in fruit set percentage was also reported by Saleem et al., (2008) and Jain et al., (2014) in mandarin. Higher percentage of fruit set was also found with the application of growth regulators such as 2, 4$\mathrm{D}, \mathrm{GA}_{3}$ and NAA in kinnow mandarin as reported by Azher Nawaz et al., (2011) Huang and Huang (2005) in Nanfengmiju mandarin and Agusti et al., (1982) in Navelate sweet orange.

Gibberellic acid has been shown to increase fruit set and growth in Clementine orange (Van Rensburg et al., 1996) (Table 1).

\section{No: of fruits per shoot}

Highest number of fruits per shoot (6.20) was recorded with application of Paclobutrazol @ $5 \mathrm{ml}$ per meter for four times starting from July to December $\left(T_{3}\right)$ followed by spraying NAA @ 200 ppm (4.05) during December $\left(\mathrm{T}_{4}\right)$. Whereas, values for other treatments spraying 2, 4-D @ 40 ppm during November
+ 20 ppm during February $\left(\mathrm{T}_{5}\right)$ (3.84), spraying $\mathrm{GA}_{3} 50$ ppm during June + CCC @ $1000 \mathrm{ppm}$ during September $+\mathrm{KNO}_{3} 2 \%$ during October $\left(\mathrm{T}_{1}\right)$ (3.48) and 30 days of soil moisture stress during October with $50 \mathrm{ppm}$ ascorbic acid spray at release of stress $\left(\mathrm{T}_{6}\right)$ (3.29), sprayings $200 \mathrm{ppm} \mathrm{CCC} 1^{\text {st }}$ in August, $2^{\text {nd }}$ in September followed by light pruning in September and heavy irrigation in midOctober $\left(\mathrm{T}_{2}\right)$ (3.03), were at par with each other.

The lowest number (1.41) of fruits per shoot was in control $\left(T_{9}\right)$. Similar results have been reported by Devi et al., (2011) in acid lime. Narayanlal et al., (2013) who found increase in flowering, fruit growth and number of fruits per shoot with the application of plant growth regulators CCC @ 1000 ppm in guava cv. Allahabad Safeda.

\section{Fruit drop percentage}

Fruit drop was recorded in all the treatments and found significant differences. Significantly lowest fruit drop (13.01) percent was recorded with spraying of 2, 4-D @ 40 ppm during November +20 ppm during February $\left(\mathrm{T}_{5}\right)$ which was found on par with spraying $\mathrm{GA}_{3} @ 50$ ppm during June + CCC @ 1000 ppm during September $+\mathrm{KNO}_{3} 2 \%$ during October (14.41), whereas highest fruit drop (43.71) percent was noticed with control treatment $\left(T_{9}\right)$ followed by spraying ethephon @ 200 ppm during December (35.31) percent.

Similar types of results were obtained by Babu and Lavaniya (1985) who have reported reduced the fruit drop percentage with spray 2,4-D @ 5-20 ppm and $\mathrm{GA}_{3} @ 20$ - 40 ppm in Pant lemon-1 and Lima and Davies (1984) in Navel orange 2, 4-D @ 10-20 ppm and $\mathrm{GA}_{3} @ 20$ ppm. Randhawa et al., (1959) found in decrease in fruit drop with spraying 2, 4-D @ 15-20 ppm in mandarins and Jaffa sweet orange. Erickson (1951) also reported 
reduction of fruit drop with spraying of 2, 4-D @ $8 \mathrm{ppm}$ in Washington navel oranges. The reason for reduction of fruit drop due to 2, 4$\mathrm{D}$ application. It is reputed for its inhibition of fruit drop in various fruit crops by delaying.
The development of abscission layer through prevention of loss of pectin material in the middle lamella. So, that stem still alive at longer time.

Table.1 Effect of plant growth regulators on percentage of fruit set, no of fruits per shoot and fruit drop percentage of summer crop in acid lime cv. Balaji

\begin{tabular}{|c|c|c|c|}
\hline Treatments & $\begin{array}{l}\text { Percentage of } \\
\text { fruit set }\end{array}$ & $\begin{array}{l}\text { No: of fruits } \\
\text { per shoot }\end{array}$ & $\begin{array}{l}\text { Fruit drop } \\
\text { percentage }\end{array}$ \\
\hline $\begin{array}{l}\mathbf{T}_{1}-\text { Spray } \mathrm{GA}_{3} @ 50 \mathrm{ppm} \text { during June }+ \\
\mathrm{CCC} @ 1000 \text { ppm during September + } \\
\mathrm{KNO}_{3} 2 \% \text { during October }\end{array}$ & $\begin{array}{l}87.95 \\
(69.73)\end{array}$ & 3.48 & $\begin{array}{l}14.41 \\
(22.30)\end{array}$ \\
\hline $\begin{array}{l}\mathbf{T}_{2}-\text { Sprayings } 200 \text { ppm CCC } \\
\text { (Chloromequat chloride) } 1^{\text {st }} \text { in august, } 2^{\text {nd }} \text { in } \\
\text { September followed by light pruning in } \\
\text { September and heavy irrigation in mid- } \\
\text { October }\end{array}$ & $\begin{array}{l}89.67 \\
(71.30)\end{array}$ & 3.03 & $\begin{array}{l}19.37 \\
(26.10)\end{array}$ \\
\hline $\begin{array}{l}\mathbf{T}_{3} \text {-Drenching Paclobutrazol @ } 5 \mathrm{ml} \text { per } \\
\text { meter canopy } 4 \text { times starting from July to } \\
\text { December }\end{array}$ & $\begin{array}{l}80.27 \\
(63.16)\end{array}$ & 6.20 & $\begin{array}{l}33.84 \\
(35.54)\end{array}$ \\
\hline $\begin{array}{l}\mathbf{T}_{4} \text { - Spraying NAA @ } 200 \text { ppm during } \\
\text { December }\end{array}$ & $\begin{array}{l}86.53 \\
(68.44)\end{array}$ & 4.05 & $\begin{array}{l}17.03 \\
(24.34)\end{array}$ \\
\hline $\begin{array}{l}\mathbf{T}_{5} \text { - Spraying 2, 4-D @ } 40 \mathrm{ppm} \text { during } \\
\text { November +20 ppm during February }\end{array}$ & $\begin{array}{l}89.97 \\
(71.54)\end{array}$ & 3.84 & $\begin{array}{l}13.00 \\
(21.11)\end{array}$ \\
\hline $\begin{array}{l}\mathbf{T}_{6}-30 \text { days of soil moisture stress during } \\
\text { October with } 50 \mathrm{ppm} \text { Ascorbic acid Spray at } \\
\text { release of stress }\end{array}$ & $\begin{array}{l}76.69 \\
(61.11)\end{array}$ & 3.29 & $\begin{array}{l}30.85 \\
(33.71)\end{array}$ \\
\hline $\begin{array}{l}\mathbf{T}_{7}-\text { Spraying ethephon @ } 200 \text { ppm during } \\
\text { October }\end{array}$ & $\begin{array}{l}71.93 \\
(58.00)\end{array}$ & 2.55 & $\begin{array}{l}35.31 \\
(36.43)\end{array}$ \\
\hline $\begin{array}{l}\mathbf{T}_{\mathbf{8}}-\text { Withholding irrigation (Bahar) for } 30 \\
\text { days in September followed by application } \\
\text { of recommended dose of fertilizers and } \\
\text { irrigation in the month of November }\end{array}$ & $\begin{array}{l}72.89 \\
(58.61)\end{array}$ & 2.95 & $\begin{array}{l}31.22 \\
33.94\end{array}$ \\
\hline $\mathbf{T}_{9}$ - Control & $\begin{array}{l}65.16 \\
(53.80)\end{array}$ & 1.41 & $\begin{array}{l}43.71 \\
(41.37)\end{array}$ \\
\hline $\mathrm{SE}(\mathrm{m}) \pm$ & 1.2 & 0.157 & 1.153 \\
\hline CD (5\%) & 3.627 & 0.474 & 3.487 \\
\hline
\end{tabular}


Table.2 Effect of plant growth regulators on no of fruits per tree and fruit yield per tree of summer crop in acid lime cv. Balaji

\begin{tabular}{|c|c|c|}
\hline Treatments & No: of fruits per tree & Fruit yield per tree \\
\hline $\begin{array}{l}\mathbf{T}_{1}-\text { Spray } \mathrm{GA}_{3} @ 50 \mathrm{ppm} \text { during June + } \\
\mathrm{CCC} @ 1000 \text { ppm during September + } \\
\mathrm{KNO}_{3} 2 \% \text { during October }\end{array}$ & 214.83 & 13.61 \\
\hline $\begin{array}{l}\mathbf{T}_{2}-\text { Sprayings } 200 \mathrm{ppm} \text { CCC } \\
\text { (Chloromequat chloride) } 1^{\text {st }} \text { in august, } 2^{\text {nd }} \\
\text { in September followed by light pruning } \\
\text { in September and heavy irrigation in mid- } \\
\text { October }\end{array}$ & 211.16 & 10.28 \\
\hline $\begin{array}{l}\mathbf{T}_{\mathbf{3}} \text {-Drenching Paclobutrazol @ } 5 \mathrm{ml} \text { per } \\
\text { meter canopy } 4 \text { times starting from July } \\
\text { to December }\end{array}$ & 234.78 & 12.08 \\
\hline $\begin{array}{l}\mathbf{T}_{4} \text { - Spraying NAA @ } 200 \text { ppm during } \\
\text { December }\end{array}$ & 222.55 & 10.11 \\
\hline $\begin{array}{l}\mathbf{T}_{\mathbf{5}} \text { - Spraying 2, 4-D @ } 40 \text { ppm during } \\
\text { November }+20 \text { ppm during February }\end{array}$ & 220.91 & 9.61 \\
\hline $\begin{array}{l}\mathbf{T}_{\mathbf{6}}-30 \text { days of soil moisture stress during } \\
\text { October with } 50 \mathrm{ppm} \text { Ascorbic acid } \\
\text { Spray at release of stress }\end{array}$ & 208.91 & 9.45 \\
\hline $\begin{array}{l}\mathbf{T}_{7}-\text { Spraying ethephon @ } 200 \text { ppm } \\
\text { during October }\end{array}$ & 212.54 & 9.30 \\
\hline $\begin{array}{l}\mathbf{T}_{\mathbf{8}}-\text { Withholding irrigation (Bahar) for } \\
30 \text { days in September followed by } \\
\text { application of recommended dose of } \\
\text { fertilizers and irrigation in the month of } \\
\text { November }\end{array}$ & 218.82 & 9.43 \\
\hline $\mathbf{T}_{9}-$ Control & 167.38 & 5.41 \\
\hline $\mathrm{SE}(\mathrm{m}) \pm$ & 2.165 & 0.067 \\
\hline CD $(5 \%)$ & 6.547 & 0.202 \\
\hline
\end{tabular}

\section{Number of fruits per tree}

The data pertaining to numbers of fruits harvested per tree has differed significantly between the treatments. Among the various treatments evaluated number of fruits per tree was found significantly highest (234.78) with the treatment application of Paclobutrazol @ $5 \mathrm{ml}$ four times starting from July to December $\left(\mathrm{T}_{3}\right)$ which was followed by spraying NAA @ 200 ppm during December (222.56) and all other treatments in the study were found on par with each other. However, lowest number of fruits (167.38) per tree was recorded with the water spray (control). The results are in conformity with findings of Tripathi and Dhakal (2005) and Devi et al., (2011) in acid lime. Goguey (1990) reported increase in the number of fruits per tree with the application of Paclobutrazol $5 \mathrm{ml}$ per tree. Paclobutrazol significantly increases.

\section{Fruit yield per tree}

Significant differences were noticed in the yield of acid lime tree due to the sprayings of 
different plant growth regulators. Spraying $\mathrm{GA}_{3} @ 50$ ppm during June + CCC @ 1000 ppm during September $+\mathrm{KNO}_{3} @ 2 \%$ during October $\left(\mathrm{T}_{1}\right)$ has recorded significantly highest fruit yield per tree $(13.61 \mathrm{~kg})$ compared to all other treatments fallowed by application of Paclobutrazol @ 5 ml per meter for four times starting from July to December $(12.08 \mathrm{~kg})$. The lowest fruit yield was recorded in control treatment $(5.41 \mathrm{~kg})$. Similar results were obtained by Mukunda et al., (2014) in acid lime. The increased fruit yield attributed to the synthesis of chlorophyll from source to sink which leads to increase carbohydrate metabolism. This might be due to more vegetative growth attained with $\mathrm{GA}_{3}$, which increased the vegetative shoot development at the initial sprays. Cycocel sprays during September enhancing flower bud initiation. $\mathrm{KNO}_{3}$ sprays at later stages could have helped to set more fruits leading highest yield per tree. The results are in agreement with the findings of Thirugnanavel et al., (2007) in acid lime, Jain et al., (2014) high yield noticed with $\mathrm{GA}_{3} 100$ ppm in Nagpur mandarin. Narayanlal et al., (2013) who reported the highest yield per plant was found in 50 ppm $\mathrm{GA}_{3}$ in guava. Debbarma and Hazarika (2016) also reported the $\mathrm{GA}_{3} @$ 100 ppm + CCC @ 1000 ppm + $\mathrm{KNO}_{3} 1 \%$ increases the yield in acid lime (Table 2).

From the investigations it can be concluded that higher fruit set was recorded with the treatment application of 2, 4-D @ 40 ppm during November +20 ppm during February $\left(\mathrm{T}_{5}\right)$, highest number of fruits per shoot was recorded with application of Paclobutrazol @ $5 \mathrm{ml}$ per meter for four times starting from July to December $\left(T_{3}\right)$, lowest fruit drop percent was recorded with spraying of 2, 4-D @ 40 ppm during November +20 ppm during February $\left(T_{5}\right)$, number of fruits per tree was recorded with the treatment application of Paclobutrazol@5 ml four times starting from July to December $\left(\mathrm{T}_{3}\right)$ and Spraying $\mathrm{GA}_{3} @$
50 ppm during June + CCC @ 1000 ppm during September $+\mathrm{KNO}_{3} @ 2 \%$ during October $\left(\mathrm{T}_{1}\right)$ has recorded significantly highest fruit yield per tree.

\section{References}

Agusti, M, Garcia, M.F. and Guardiola, J.L. 1982. The influence of flowering intensity on the shedding of reproductive structure in sweet orange. Scientia Horticulture. 17: 343-352.

Azher Nawaz, M, Afzal, M, Waqar, A, Ashraf, M, Jaime, A, Silva, T, Akthar, N, Shahzad, S.M, Hameed, U. and Zahoor, H. 2011. Exogenous application of 2, 4-D, $\mathrm{GA}_{3}$ and NAA at flowering improves yield and quality of Kinnow mandarin (Citrus reticulate Blanco). The Asian and Australian Journal of Plant Science and Bio technology. 5(1): 17-21.

Babu, R. (2001). Lime and lemons. Handbook of horticulture, ICAR. New Delhi. 212 pp.

Babu, R.G.H.V. and Lavaniya, M.L. 1985. Effect of plant growth regulators on fruit set, fruit drop of Pant lemon-1. Indian Journal of Horticulture. 42: 237240.

Debbarma, N. and Hazarika, B.N. 2016. Effect of plant growth regulators and chemicals on yield and quality of acid lime (Citrus aurantifolia Swingle) under foot hill condition of Arunachal Pradesh. International Journal of Agriculture, Environment and Biotechnology. 9(2): 231-236.

Devi, H.L, Sarkar, S.K, Dhanabati, L. and Majhi, D. 2011. Flushing - flowering behavior and regulation in acid lime. Journal of Crop and Weed. 7(2): 87-90.

Ghosh, S.N, Bera, B. and Ray, S. 2012. Influence $f$ plant growth regulators on fruit production of sweet orange. Journal of crop and Weed. 8(2): 83-85. 
Goguey, T. 1990. The effect of repeated application of cultar (paclobutrazol) to Mangifera indica L.var. Valencia. Fruit-Paris. 45(6): 599-607.

Huang, J.H. and Huang, L. 2005. The application of $\mathrm{GA}_{3}$ in citrus orchards. South China Fruits. 3: 32-36.

Jain, M.C, Choudhary, H.D, Sharma, M.K. and Bhim Singh. 2014. Yield and quality attributes of Nagpur mandarin as affected by use of different plant growth regulators. Environment and Ecology 32: 1141-45.

Lima, J.E.O. and Davies, F.S. 1984. Growth regulators, fruit drop, yield and quality of Navel orange in Florida. Journal of the American Society for Horticultural Science. 109: 81-84.

Mukunda, L.L, VenkataRamana, K.T, SivaramaKrishna, V.N.P, Yuvaraj, K.M, Nagalakshmi, T, Sarada, G, Gourisankar, T, Gopi, V. and Gopal, K. 2014. Effect of growth regulators and chemicals on fruit yield and quality of hasta bahar flowering in acid lime (citrus aurantifolia swingle) cv. Balaji. Journal of Agriculture and Allied Sciences. 3(3): 11-13.

Narayanlal, Das, R.P. and Verma, L.R. 2013. Effect of plant growth regulators on flowering and fruit growth of guava (Psidium guajava L.) cv. Allahabad safeda. The Asian Journal of Horticulture. 8(1); 54-56.

Panse, M. and Sukhathme, K. 1985. Statistical methods for agriculture workers. Indian Council of Agriculture Research Publications. 48-67.
Randhawa, G.S, Singh, J.P. and Dhuria, H.S. 1959. Effect of $\mathrm{GA}_{3}, 2,4-\mathrm{D}$ and 2, 4, 5$\mathrm{T}$ on fruit set, fruit drop and total yield of sweet lime (Citrus limenttiodes Tanaka). Indian Journal of Horticulture. 16(4): 206-209.

Rangel, C.N, Carvalho, L.M.J, Fonseca, R.B.F, Soares, A.G. and Jesus, E.O. 2010. Nutritional values of organic acid lime. Food Science and Technology. 31(4): 918 - 922.

Saleem, B.A, Malik, A.U, Pervez, M.A, Khan, A.S. and Khan, A.M. 2008. Spring application of growth regulators affects fruit quality of Blood Red sweet orange. Pakistan Journal of Botany. 40: 1013-1023.

Thirugnanavel, A, Amutha, R, BabyRani, W. and Indira, K. 2007. Studies on regulation of flowering in Acid lime (Citrus aurantifolia swingle). Research journal of agriculture and biological sciences. 3: 239-241.

Tripathi, K.M. and Dhakal, D.D. 2005. Effect of paclobutrazol on off-season flower induction in acid lime (Citrus aurantifolia Swingle) land races under Chitwan condition. Journal of the Institute of Agriculture and Animal Science. 26: 87-92.

Van Rensburg, P, Shung-Shi, P, García-Luis Fornés A.F. and Guardiola, J.L. 1996. Improving crop value in Fino Clementine mandarin with plant growth regulators. Proceedings of the International Society of Citriculture. 2: 970-974.

\section{How to cite this article:}

Ranganna, G., K.T. Venkataramana, L. Mukundalakshmi, K. Swarajyalakshmi and Sudhakar, P. 2017. Effect of Plant Growth Regulators on Fruit Set and Yield of Summer Crop in Acid Lime (Citrus aurantifolia Swingle) cv. Balaji. Int.J.Curr.Microbiol.App.Sci. 6(6): 2208-2214. doi: https://doi.org/10.20546/ijcmas.2017.606.261 